Dokuz Eylül Üniversitesi-Mühendislik Fakültesi

Fen ve Mühendislik Dergisi

Cilt 19, Sayı 56, Mayıs 2017
Dokuz Eylul University-Faculty of Engineering Journal of Science and Engineering Volume 19, Issue 56, May 2017

DOI: $10.21205 /$ deufmd.2017195657

\title{
Urban Accessibility and Affordability: A Case Study for Istanbul
}

\author{
Sabahat TOPUZ KİREMITTÇi ${ }^{* 1}$, Haluk GERÇEK ${ }^{1}$ \\ ${ }^{1}$ İstanbul Teknik Üniversitesi, İnşaat Fakültesi, İnşaat Mühendisliği Bölümü, 34469, \\ İstanbul
}

(Alınış / Received: 31.05.2016, Kabul / Accepted: 26.12.2016, Online Yayınlanma / Published Online: 02.05.2017)

Keywords

Urban

Accesibility,

Affordability,

Joint Logit Model

\begin{abstract}
Application of sustainable transportation policies for resolving the transportation problem of Istanbul that has a population of 14.7 million in 2015 is of vital importance. This study focuses on economical and social goals of sustainable transportation by researching the relationship between urban accessibility, affordability and the transportation system. The purpose of this study is to investigate the combined role of affordability and accessibility and to introduce an accessibility measure to compare different transportation infrastructure schemes in Istanbul. For this purpose, the accessibility has been measured by means of a joint logit model. The main outcomes have been shown on an accessibility map and an elasticity analysis has been presented for different user groups. It has been concluded that accessibility is much higher in the central areas and decreases in the outskirts of the city. Results of the joint logit function have indicated that the effects of gender, income and car availabilities on mode choice are significant. The elasticity analysis has shown that mode choice decisions of car users are not sensitive to the transportation cost.
\end{abstract}

\section{Kentsel Erișilebilirlik Ve Ödenebilirlik: İstanbul İçin Bir Durum İncelemesi}

\begin{abstract}
Anahtar Kelimeler Özet: 2015 yılı itibarıyla 14,7 milyon nüfuslu İstanbul'un ulaşım Kentsel Erişilebilirlik, Ödemebilirlik, Birleşik Logit Model
\end{abstract}


logit model sonuçları cinsiyet, gelir, otomobil sahipliliği değişkenlerinin tür seçimi üzerinde önemli bir etkisinin olduğunu vurgulamaktadır. Esneklik analizi, otomobil kullanıcılarının tür tercihi kararlarının ulaşım maliyetine duyarlı olmadığını göstermiștir.

*Sorumlu yazar: topuzsa@itu.edu.tr

\section{Introduction}

Transport and infrastructure development enables economic and social development but is often detrimental to sustainable development due to congestion, accidents, air pollution as well as greenhouse gas emissions [1]. Thus, decisions and policies about transport and transport related infrastructure investments should be made with great precision, especially in developing countries with tighter budgets. There are several studies focusing on how transportation policies can be decided ethically and equally [2]. However, there are no specific or solid indicator to measure how these investments can contribute to promoting better access to opportunities particularly for the most vulnerable segments of the population [3].

Evaluations of transport policy plans are generally based on cost-benefit analyses. Accessibility changes are included in such analyses indirectly. But accessibility is broader than is assumed by this perspective and also incorporates equity and related distribution effects as well as social exclusion [4]. This paper aims at presenting a new approach (perspective) to accessibility in evaluation of urban transport investments, focusing on sustainability related social elements such as equity and urban transportation affordability. Accessibility refers to the ease of reaching goods, services, activities and destinations, which together are called opportunities. There are different types of accessibility measures. In this study, a utility based accessibility measure is prefered because of its higher capability of reflecting social and economical effects. Even utility based accessibility measures usually uses transportation cost only as variable instead of transportation affordability [5-6]. This study is targeting to use affordability as a variable in accessibility calculations.

Within this scope, Istanbul is chosen as the case city because of that it is a megacity trying to cope with income inequalities, irrepressible transport related problems and extensive transport infrastructure investments. On the contrary to global research arena, accessibility studies are limited in Turkey [7-11].

The next section of the paper gives a brief information about the study area. Section 3, describes accessibility and transportation affordability, and explains data and method used in the analysis. Concluding section discusses the results and further studies that have to be done.

\section{About Istanbul}

Istanbul is a unique megacity with over 14 million inhabitants spread both Asian and European sides of the Bosphorus. North of the city is mostly rural and forest areas. According to Istanbul Transportation Master Plan Household Study [12] data, population densities are higher on the southern of the city (Figure 1). On the other hand, distribution of working people seems more widespread (Figure 2). 


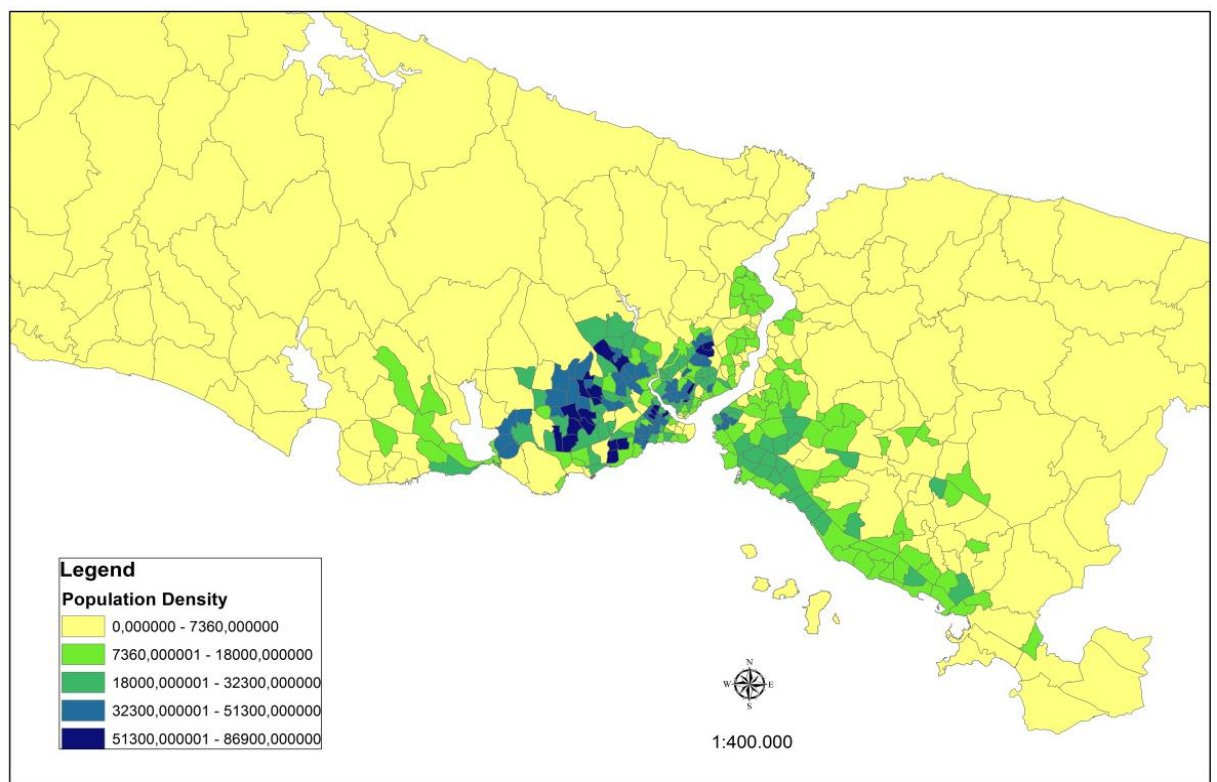

Figure 1. Population density in Istanbul (2007)

Districts with highest number of working people are close to the districts with highest number of employment, which are generally industrial areas (Figure 3).
Distribution of household income does not present a distinctive geographical pattern (Figure 4). It is often possible to spot a high income zone surrounded by low income zones and vice versa.

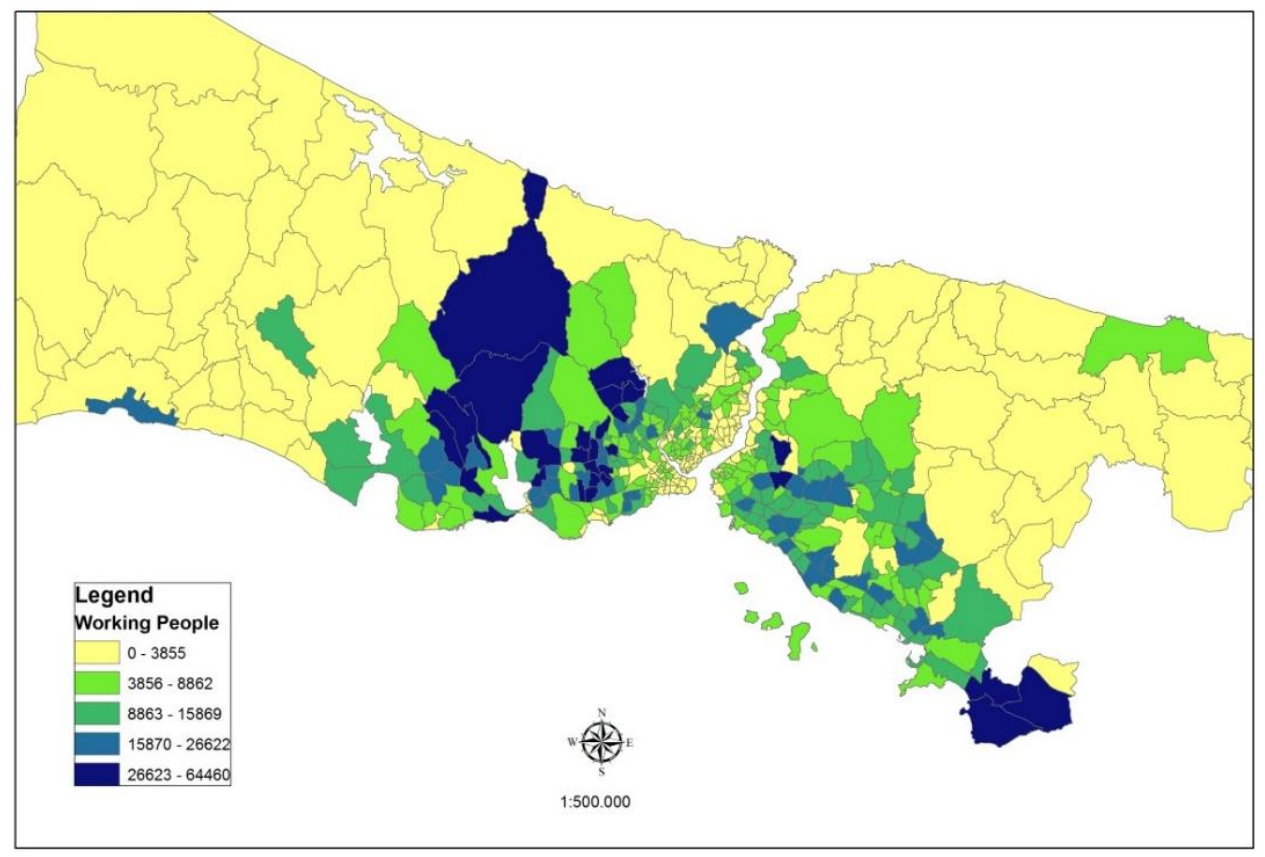

Figure 2. Number of working people in Istanbul (2007) 


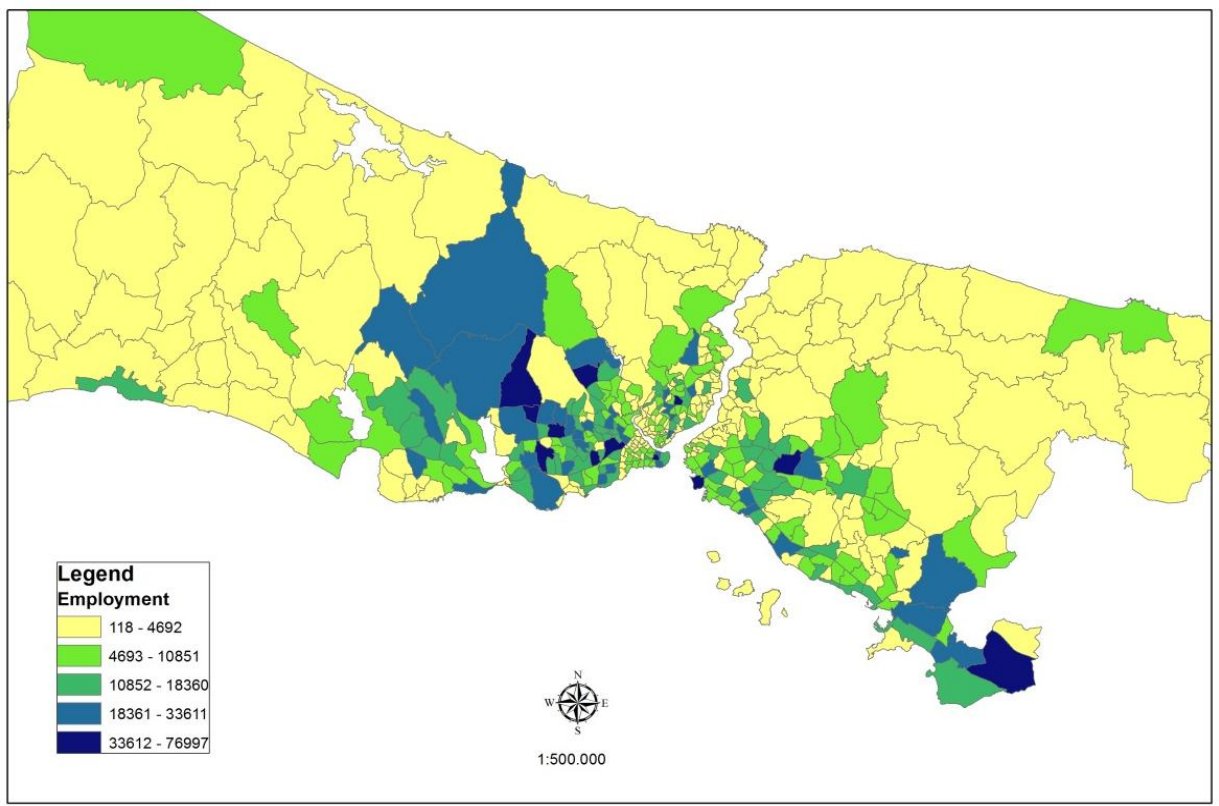

Figure 3. Number of employment in Istanbul (2007)

Car ownership distribution (Figure 5) of the city has shown similar characteristics with income distribution, i.e., zones with highest car ownership values are the zones of higher income groups.
Despite its relatively large area and massive population, the public transport system is mostly road-based and not sufficient to meet the travel demand. As shown in Figure 6 and Figure 7, transportation network of the city is road dominated.

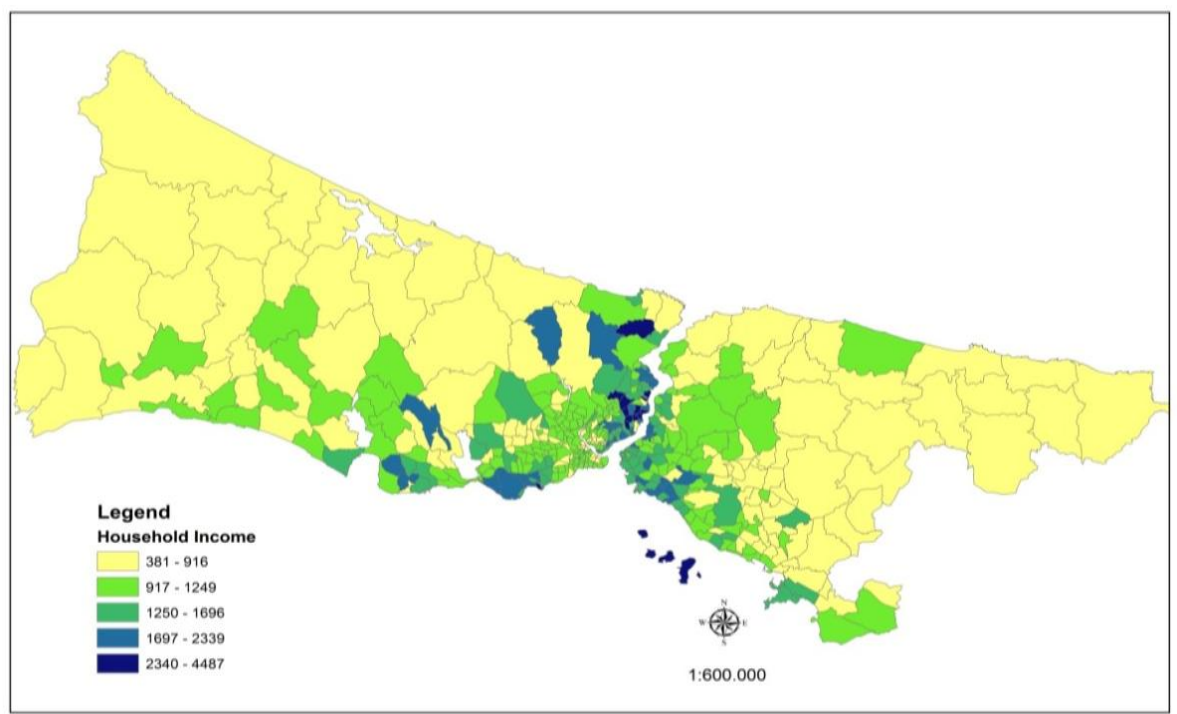

Figure 4. Household income distribution (2007) 


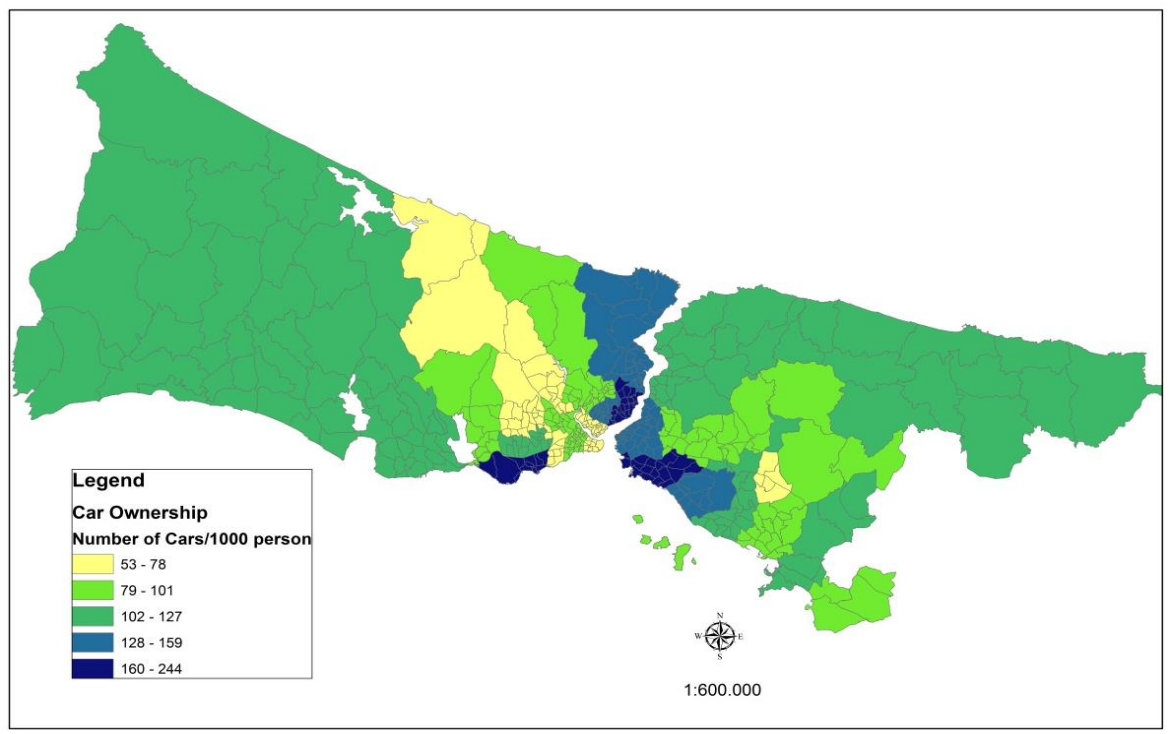

Figure 5. Car ownership distribution (2007)

Railway system is inadequate and although city is divided by the Bosphorus, the share of sea transport is dramatically low. Three highway bridges crossing the Bosphorus Strait carry road traffic between Asian and European sides of the city. Relatively higher number of job places are located in the European side $(73 \%$ of jobs and $65 \%$ of inhabitants) and this creates a high travel demand in the east-west direction in the morning and opposite direction in the evening peak hours. The bottlenecks created by the two bridges and unbalanced travel demand causes long queues and traffic congestion not only in morning and evening peaks but almost all day long.

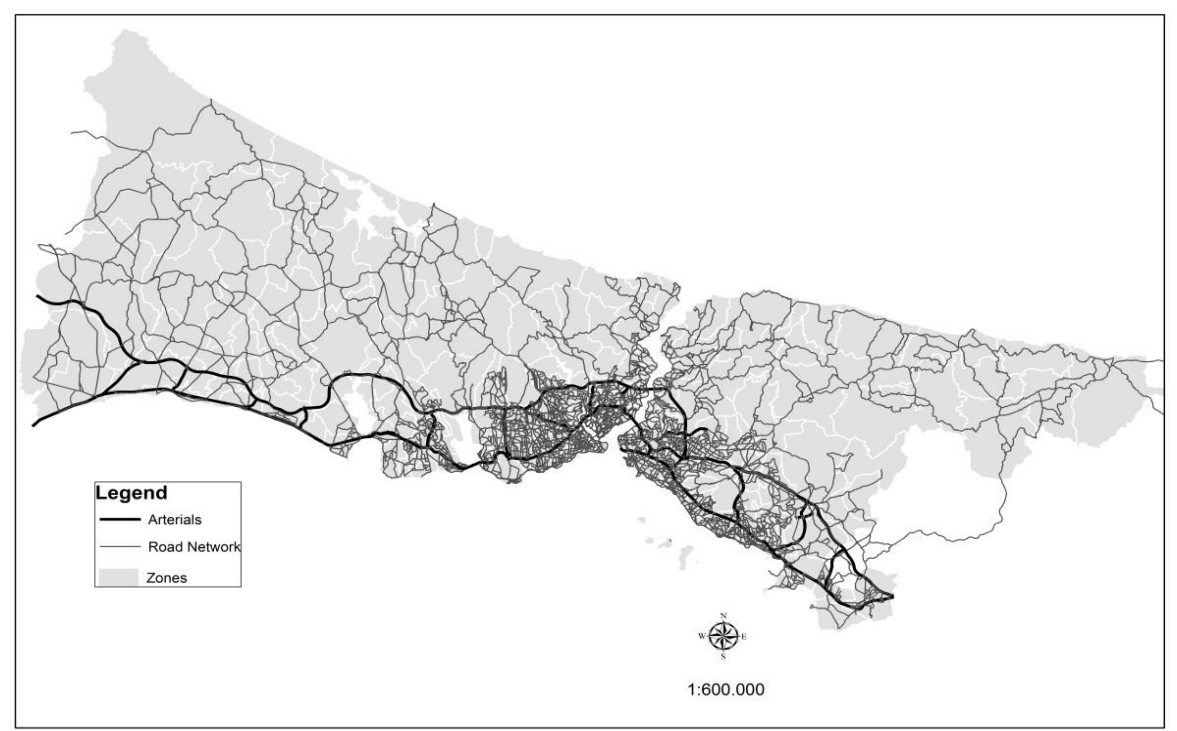

Figure 6. Road network of Istanbul (2007) 


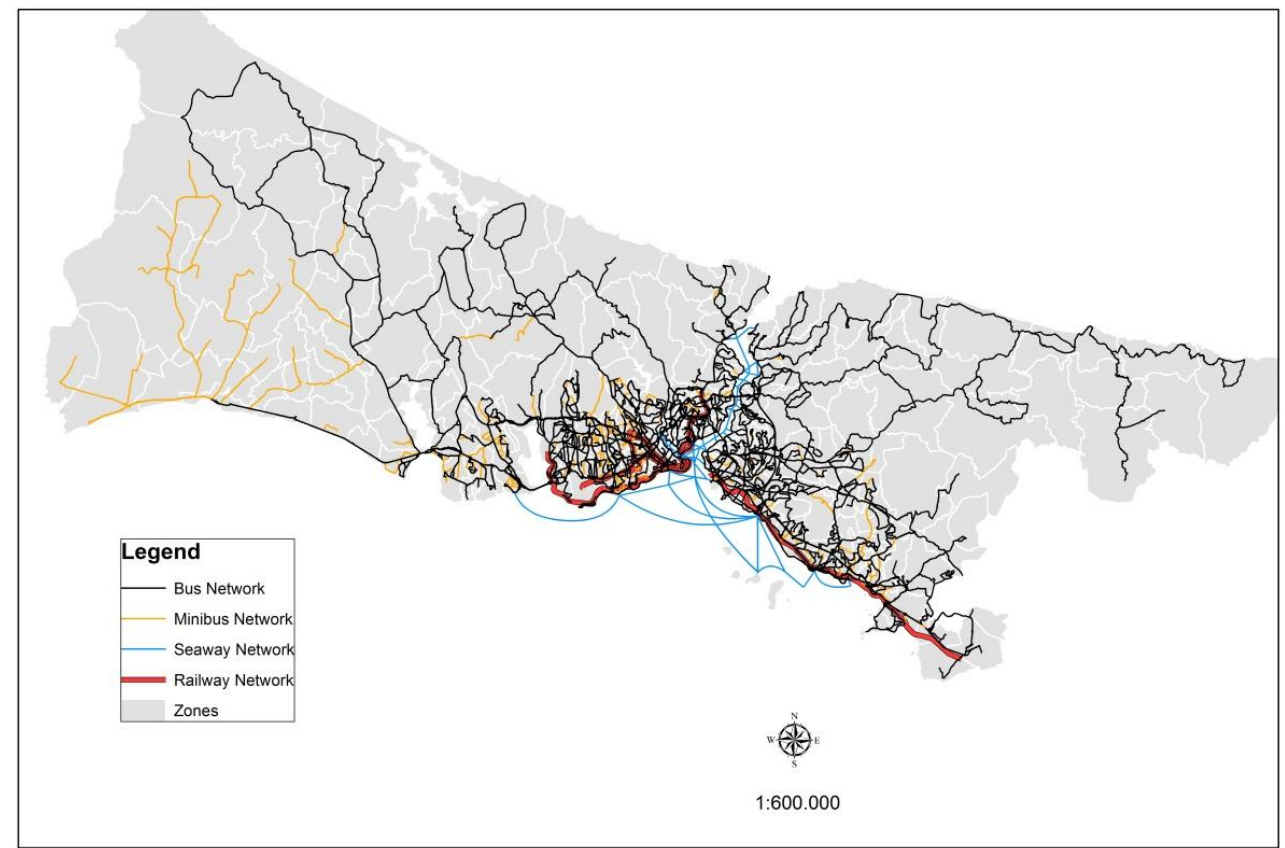

Figure 7. Public transportation network of Istanbul (2007)

\section{Methodology}

Transportation affordability means that user financial costs of transport are not excessive, particularly for basic access. According to Litman [13], it means that people can purchase access to basic goods and activities (medical care, basic shopping, education, work and socializing), which typically means that low- and medium-income households spend less than $20 \%$ of their budgets on transport and less than $45 \%$ on transport and housing combined. The terms, sustainability and affordability require improving transportation modes like public transport, cycling and walking. Affordability is also important for transport related social exclusion and transport equity, especially for low income groups. There are significant number of studies about relations between accessibility, affordability and equity [14-18].
On the other hand, accessibility is a term often used by transportation experts from both academic and practical backgrounds. It has many definitions in literature such as: the potential of opportunity for interaction [19], overall benefits provided by a given transport system [20] and, the ease of reaching goods, services, activities and destinations, which together are called opportunities [21]. For an overview of the literature on accessibility see, for example, Handy and Niemeier [22] or Páez et al. [23]. According to Geurs and Van Wee [24] accessibility measures can be categorized according to their components which are land-use, transport and individual elements. Besides its several advantages, an utility based approach is used in this study especially for its capability of representing all these three components [25]. 
Choise models are frequently used in accessibility studies [26]. There are several utility based accessibility measures available in the literature like multinomial logit, joint logit [2729] and nested logit models [30]. In order to estimate both destination and mode choices of travellers, joint logit models and nested logit models are applicable. Nested logit has a sequential tree structure but joint logit model estimates destination and mode choices together. A joint logit model has been preferred in this study due to its relatively simpler structure.

\subsection{Data}

Home-based work trips data from the household travel surveys that were carried out in 2006 for Istanbul Transportation Master Plan Study [12] have been provided by the Transportation Planning Department of Istanbul Metropolitan Municipality. The data contains information of approximately 20,000 home-based work trips from 451 traffic analysis zones of Istanbul. In this study, private car and public transport trips of about 8,000 individuals have been used.

\subsection{Joint Logit Model}

Suppose that a multidimensional choice set $\mathrm{Cn}$ for individual $\mathrm{n}$, whose elements are defined as mode and destinations. Let us define $\mathrm{Udm}$ as the total utility of the element of $\mathrm{Cn}$ consisting of mode $\mathrm{m}$ and destination $\mathrm{d}$. It is assumed that some elements $\mathrm{Cn}$ share common observed elements as a consequence of their sharing the same mode or destination. By extension of the partition of the total utility into systematic and random components, it can be written as,

$$
\begin{gathered}
U_{d m}=V_{d}+V_{m}+V_{d m}+\varepsilon_{d m} \\
\forall(\mathrm{d}, \mathrm{m}) \in \mathrm{C}_{\mathrm{n}}
\end{gathered}
$$

where,

$V_{d}$ is the systematic component of utility common to all elements of $C_{n}$ using destination $d, \mathrm{~V}_{\mathrm{m}}$ is the systematic component of utility common to all elements of $C_{n}$ using mode $m, V_{\mathrm{dm}}$ is the remaining systematic component of utility specific to the combination $(d, m)$ and $\varepsilon_{\mathrm{dm}}$ is the random utility component.

Our model has the following variables for alternative $i \in C_{n}$ :

$x_{i 1}$ is the travel time for mode/destination combination $i, x_{i 2}$ is the out-of-pocket cost for mode mode/destination combination $i$ divided by monthly household income (affordability term of the model), $x_{i 3}$ is the employment ratio at the destination included in alternative $\mathrm{i}, x_{i 4}$ is a a gender-specific constant defined as 1 if the gender is male and 0 for otherwise, $x_{i 5}$ is car availability defined as 1 if the household owns one auto and 0 for otherwise, $x_{i 6}$ is car availability defined as 1 if the household owns more than one auto and 0 for otherwise, $x_{i 7}$ is the mode specific constant.

Here, the first two variables $x_{i 1}$ and $x_{i 2}$ would be part of $V_{\mathrm{dm}}$ because they vary across both the mode and destination. Variable $x_{i 3}$ would be part of $V_{d}$ because its value do not vary across elements of $C_{n}$ using $d$; any mode and destination combinations having the same destination have the same values of $x_{i 3}$. Finally $x_{i 4}, x_{i 5}$ and $x_{i 6}$ vary only across modes. Two dummy variables $\left(x_{i 5}\right.$ and $\left.x_{i 6}\right)$ are used to represent households having zero, one and more than one cars.

Thus,

$$
V_{d m}=\beta_{1} x_{i 1}+\beta_{2} x_{i 2}
$$




$$
\begin{gathered}
V_{d}=\beta_{3} x_{i 3} \\
V_{m}=\beta_{4} x_{i 4}+\beta 5 x_{i 5}+\beta_{6} x_{i 6}+\beta_{7}
\end{gathered}
$$

The distribution of the $\varepsilon_{\mathrm{dm}}$ 's across the alternatives and across the population defines the choice probabilities. Multinomial logit model has been used for the joint choice of destination and modes, assuming these disturbances are independent and identically gumbel distributed (with the scale parameter $\mu$ normalized to 1 ) as follows:

$$
P_{n}(d, m)=\frac{e^{V_{m}+V_{d}+V_{d m}}}{\sum_{(m, d) \in C_{n}} e^{V_{m}+V_{d}+V_{d m}}}
$$

Equation above is called the joint logit model. Let i denote $(d, m)$ destination/mode choice combination, natural logarithm of equation (5)'s denominator is used as accessibility measure for individual $n$.

$$
A_{n}=\ln \sum_{i \in C_{n}} e^{V_{m}+V_{d}+V_{d m}}
$$

\subsection{Aggregate Accessibility Measure} For spatial accessibility analysis, it is necessary to produce some accessibility-affordability measures aggregated on zonal basis. The aggregate accessibility measure of a zone $z$ can be calculated by applying the joint disaggregate measure of individuals to each group (category) in that zone and expanding these accessibilities to the entire population of zone $z$.

In order to do this, population in each zone $z$ is divided into $K$ nearly homogenous subgroups with sizes $N 1$, $N 2, \ldots, N k$. The number of groups may be calculated by equation (7).

$$
\begin{gathered}
K=N_{g} \cdot N_{c} \cdot N_{i} \\
K=2 \times 3 \times 3=18\left(k=1, N_{k}\right)
\end{gathered}
$$

where,

$\mathrm{K}$ is the number of groups, $\mathrm{N}_{\mathrm{g}}$ is the number of gender groups (male, female) which is equal to $2\left(\mathrm{~g}=1, \mathrm{~N}_{\mathrm{g}}\right)$, $\mathrm{N}_{\mathrm{c}}$ is the number of car-ownership groups (no car available, 1 car available, more than 1 can available per household) which is equal to 3 ( $\mathrm{c}=1, \mathrm{~N}_{\mathrm{c}}$ ), and $\mathrm{N}_{\mathrm{i}}$ is the number of household income groups $(0-1000$ TL/month, low, 1000-3000 TL/month, middle, > $3000 \mathrm{TL} /$ month, high) which is equal to $3\left(\mathrm{i}=1, \mathrm{~N}_{\mathrm{i}}\right)$.

Equations (2), (3) and (4) can be written as equations (8), (9) and (10) by using variables $\overline{\mathrm{x}}_{\mathrm{zi} 1}$ (average travel time from zone $\mathrm{z}$ for mode/destination choice i) and $\bar{x}_{\mathrm{zij}}$ (average out-ofpocket travel cost / household income group j).

$$
\begin{gathered}
\bar{V}_{z i j}=\beta_{1} \cdot \bar{x}_{z i 1}+\beta_{2} \cdot \bar{x}_{z i j} \\
V_{d}=\beta_{3} \cdot x_{i 3} \\
V_{m g c}=\beta_{4} x_{i 4}+\beta_{5} x_{i 5}+ \\
\beta_{6} x_{i 6}+\beta_{7}=V_{m k}
\end{gathered}
$$

Therefore, utility of zone $z$ for category $k$ becomes,

$$
U_{z k i}=V_{d}+\bar{V}_{z k j}+V_{m k}
$$

Accessibility measure of zone $\mathrm{z}$ for category $\mathrm{k}$ is defined by,

$$
A_{z k}=\ln \sum_{i} e^{U_{z k i}}
$$

Then, the aggregated accessibility measure for zone $z$ is defined by the formula given below, where $W_{z k}$ is the number of working people in zone $\mathrm{z}$ belong to category $k$.

$$
\begin{aligned}
& A_{z}=\sum_{k} W_{z k} \cdot A_{z k} \\
& A_{z}=\sum_{k} W_{z k} \cdot \ln \sum_{i} e^{U_{z k i}}
\end{aligned}
$$




\section{Results}

\subsection{Results of the Joint Logit Model}

The estimated coefficients and $t$ statistics of the joint logit model for mode and destination choices are given in Table 1.

Table 1. Estimation results of Joint Logit

\begin{tabular}{|c|c|c|}
\hline \multicolumn{3}{c}{ Model } \\
\hline Variable & Coefficient & t-stats \\
\hline$\beta_{1}$ & -0.04504802 & $-37.402^{*}$ \\
\hline$\beta_{2}$ & -5.26844073 & $-20.415^{*}$ \\
\hline$\beta_{3}$ & 4.53209045 & $16.245^{*}$ \\
\hline$\beta_{4}$ & 0.95696531 & $13.712^{*}$ \\
\hline$\beta_{5}$ & 2.40162860 & $42.050^{*}$ \\
\hline$\beta_{6}$ & 2.80048098 & $29.593^{*}$ \\
\hline$\beta_{7}$ & -3.32058474 & $-40.286^{*}$ \\
\hline * Significant at 95\% confidence level \\
\hline
\end{tabular}

According to t-statistics, the variables are significant and the pseudo- $\mathrm{R}^{2}\left(\rho^{2}\right)$ value, which is 0.21 , for the model also suggests a moderate model on the basis of overall goodness-of-fit.

\subsection{Results of the Spatial Analysis}

After the calculation of aggregated accessibilities, the results have been visualized by the ArcMap and shown in Figure 8. From the figure, it is possible to distinguish three rings with different degrees of accessibility in the central area of Istanbul.

The core area (measured via ArcGISß according to accessibility colour contours) consists of an ellipse with $\mathrm{R}_{1}=5.8 \mathrm{~km}$ and $\mathrm{R}_{2}=7.9 \mathrm{~km}$ radius covering the Historical Peninsula, Fatih, Beyoğlu and parts of the Bakırköy, Beşiktaş, Üsküdar and Kadıköy districts. This core area is surrounded with a relatively narrow second ring with an average width of 3 $\mathrm{km}$ covering parts of Bakırköy, Bahçelievler, Beşiktaş, Güngören, Bağcılar, Esenler, Gaziosmanpaşa, Eyüp, Bayrampaşa, Kağıthane, Kadıköy, Üsküdar, Şişli and Zeytinburnu. The third ring has a width of approximately $4.8 \mathrm{~km}$ and covers the districts of Ümraniye, Kartal, Sultanbeyli, Maltepe, Küçükçekmece and some parts of Sarlyer and Beykoz. The triangle outside these three rings covers the zones with relatively less populated areas with less job densities. The outer zones in the rest of the map are generally rural areas whit low degree of accessibility.

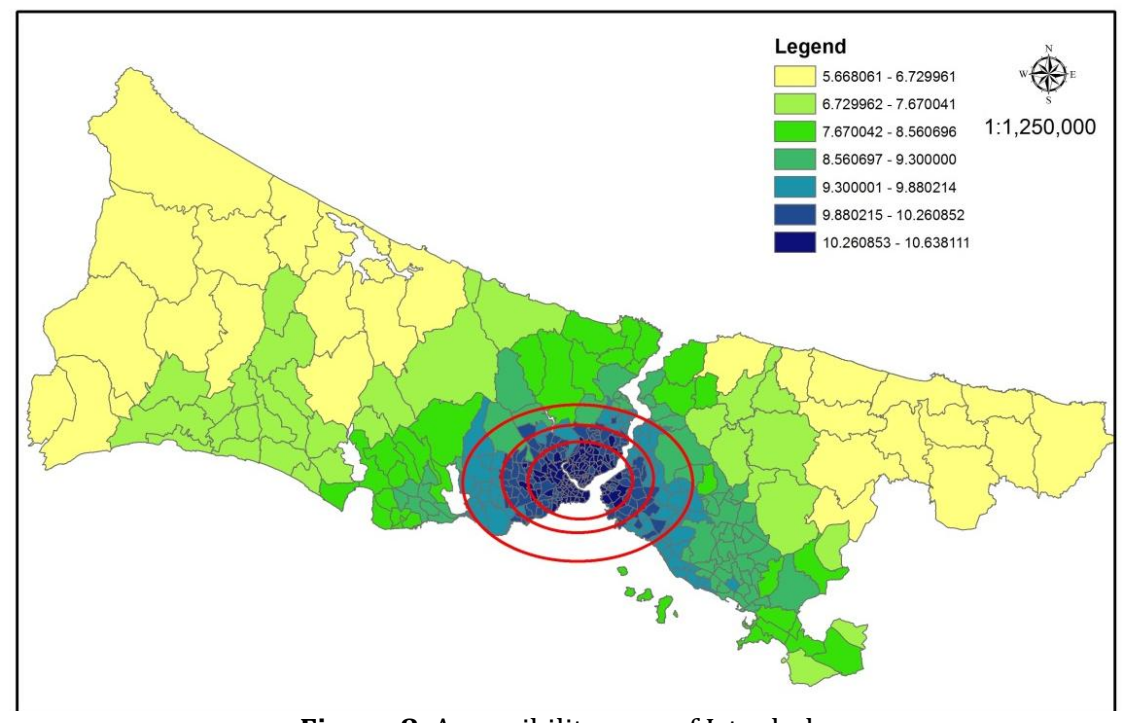

Figure 8. Accessibility map of Istanbul 


\subsection{Elasticities}

A disaggregate elasticity represents the responsiveness of an individual's choice probability to a change in the value of the selected attribute [31].

Let $\mathrm{E}_{\mathrm{xi}}^{\mathrm{P}_{\mathrm{n}}(\mathrm{i})}$ be the elasticity of the probability of an individual choosing alternative $i$ with respect to a change in some attribute $x_{i}$ which is an independent variable in the model.

$$
\begin{aligned}
& \mathrm{E}_{\mathrm{xi}}^{\mathrm{P}_{n}(\mathrm{i})}=\frac{\partial \mathrm{P}_{\mathrm{n}}(\mathrm{i})}{\partial \mathrm{x}_{\mathrm{i}}} \cdot \frac{\mathrm{x}_{\mathrm{i}}}{\mathrm{P}_{\mathrm{n}}(\mathrm{i})}= \\
& \frac{\partial \ln \mathrm{P}_{\mathrm{n}}(\mathrm{i})}{\partial \ln \mathrm{x}_{\mathrm{i}}}=\left[1-\mathrm{P}_{\mathrm{n}}(\mathrm{i})\right] \mathrm{x}_{\mathrm{i}} \beta_{\mathrm{k}}
\end{aligned}
$$

Likewise, the disaggregate cross elasticity of the probability of an individual choosing alternative $i$ that is selected with respect to a change in alternative $j$ is,

$$
E_{x j}^{P_{n}(i)}=\frac{\partial \ln P_{n}(i)}{\partial \ln x_{j}}=-P_{n}(j) x_{j} \beta_{k}
$$

In order to calculate elasticities, individuals have been categorized into 18 groups according to their gender (male, female), household income level (low, middle, and high), and car availability of the household (no car available, one car available, and more than one car available). An origindestination zone pair is selected and changes in utilities have been calculated for each of 18 categories and for 2 cases: In Case 1, private car users costs have been increased by 10 $\%$ and $15 \%$. In Case 2, public transportation travel times have been reduced by $10 \%$. Elasticities for Case

\begin{tabular}{|c|c|c|c|c|c|c|c|c|c|c|c|}
\hline \multirow[b]{2}{*}{$\begin{array}{l}\vec{D} \\
0 \\
0 \\
0 \\
0 \\
0\end{array}$} & \multirow[b]{2}{*}{ 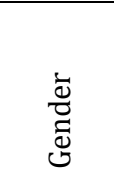 } & \multirow[b]{2}{*}{ 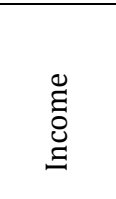 } & \multirow[b]{2}{*}{ đँ } & \multicolumn{2}{|c|}{ Base Case } & \multicolumn{3}{|c|}{ Case 1} & \multicolumn{3}{|c|}{ Case 2} \\
\hline & & & & $\mathrm{P}_{\mathrm{A}}$ & РРт & $\mathrm{P}_{\mathrm{A}}$ & РРт & $\mathbf{E}$ & $\mathrm{P}_{\mathrm{A}}$ & $\mathrm{P}_{\mathrm{PT}}$ & $\mathbf{E}$ \\
\hline 1 & Male & Low & 0 & 0.01 & 0.99 & 0.01 & 0.99 & -2.87 & 0.01 & 0.99 & 2.23 \\
\hline 2 & Male & Low & 1 & 0.13 & 0.87 & 0.08 & 0.92 & -2.67 & 0.10 & 0.90 & 1.97 \\
\hline 3 & Male & Low & $1+$ & 0.18 & 0.82 & 0.11 & 0.89 & -2.57 & 0.15 & 0.85 & 1.85 \\
\hline 4 & Male & Middle & 0 & 0.09 & 0.91 & 0.08 & 0.92 & -0.81 & 0.08 & 0.92 & 2.05 \\
\hline 5 & Male & Middle & 1 & 0.53 & 0.47 & 0.49 & 0.51 & -0.45 & 0.47 & 0.53 & 1.06 \\
\hline 6 & Male & Middle & $1+$ & 0.63 & 0.37 & 0.59 & 0.41 & -0.36 & 0.57 & 0.43 & 0.84 \\
\hline 7 & Male & High & 0 & 0.13 & 0.87 & 0.12 & 0.88 & -0.40 & 0.10 & 0.90 & 1.97 \\
\hline 8 & Male & High & 1 & 0.61 & 0.39 & 0.60 & 0.40 & -0.18 & 0.56 & 0.44 & 0.87 \\
\hline 9 & Male & High & $1+$ & 0.70 & 0.30 & 0.69 & 0.31 & -0.14 & 0.65 & 0.35 & 0.67 \\
\hline 10 & Female & Low & 0 & 0.01 & 0.99 & 0.00 & 1.00 & -2.88 & 0.00 & 1.00 & 2.24 \\
\hline 11 & Female & Low & 1 & 0.05 & 0.95 & 0.03 & 0.97 & -2.80 & 0.04 & 0.96 & 2.14 \\
\hline 12 & Female & Low & $1+$ & 0.08 & 0.92 & 0.05 & 0.95 & -2.76 & 0.06 & 0.94 & 2.08 \\
\hline 13 & Female & Middle & 0 & 0.04 & 0.96 & 0.03 & 0.97 & -0.85 & 0.03 & 0.97 & 2.17 \\
\hline 14 & Female & Middle & 1 & 0.30 & 0.70 & 0.27 & 0.73 & -0.64 & 0.26 & 0.74 & 1.57 \\
\hline 15 & Female & Middle & $1+$ & 0.39 & 0.61 & 0.36 & 0.64 & -0.57 & 0.34 & 0.66 & 1.37 \\
\hline 16 & Female & High & 0 & 0.05 & 0.95 & 0.05 & 0.95 & -0.43 & 0.04 & 0.96 & 2.14 \\
\hline 17 & Female & High & 1 & 0.38 & 0.62 & 0.36 & 0.64 & -0.29 & 0.33 & 0.67 & 1.40 \\
\hline 18 & Female & High & $1+$ & 0.48 & 0.52 & 0.46 & 0.54 & -0.25 & 0.42 & 0.58 & 1.18 \\
\hline
\end{tabular}
1 and 2 are shown in Table 2.

Table 2. Elasticities for Case 1 and for Case 2 
In Base Case (no change in auto travel cost and in public transport travel time), categories 5, 6, 8 and 9 choose private car. People in these categories are male, in middle or high income groups, and own one or more than one car. In Case 1, private car users costs have been increased by $10 \%$. In this case, none of the categories has changed their mode choices. In Case 2, private car users costs have been increased by $15 \%$. In this case, only the car users in Category 5 have shifted from private car to public transportation. As it can be seen from the elasticities of Category 5, 6, 8 and 9 , private car users are inelastic to travel cost increase (Case 1). Effect of travel time changes on mode choice is higher (even elastic for Category 5) than the effect of the travel cost.

\section{Conclusions}

The role of sustainable transport policies for a better quality of life in cities is undeniable. Policies such as improving public transportation, promoting walking and cycling, managing travel demand not only reduce the share of private cars, traffic congestion and air pollution, but also increase accessibility and create more liveable cities.

The main outcomes of this study can be summarised as follows:

-Effects of gender, income and car availabilities on mode choice are significant.

-A small portion of people, which are male, belong to middle or high income groups and own one or more private cars choose to travel by car on their home-based-work trips. It is difficult to change their mode choices by only reducing public transportation travel time or increasing costs of private car. Improving public transportation network, creating more convenient and comfortable mobility alternatives may be a better option.

-Despite the fact that most people prefer public transport system for home-based work trips, public transport network, particularly rail transit system, is still far from being sufficient to meet the increasing demand in Istanbul.

-Accessibility is much higher in the central areas and decreases in the outskirts of the city.

In order to assess the effects of different major transportation projects on accessibility, further studies are planned by using the model proposed in this paper.

\section{Acknowledgments}

Authors wishes to acknowledge anonymous reviewers for their helpful comments.

\section{References}

[1] Bakker, S., et al., 2014. Transport, Development and Climate Change Mitigation: Towards an Integrated Approach, Transport Reviews 34 (3), 2014, s. 335-355. DOI: 10.1080/01441647.2014.903531

[2] Lucas, K., van Wee, B., Maat, K., 2016. A method to evaluate equitable accessibility: combining ethical theories and accessibilitybased approaches,

Transportation 43 (3), s. 473-490. DOI:10.1007/s11116-015-95852

[3] Bocarejo, S. J. P. and H. D. R. Oviedo, 2014. Transport accessibility and social inequities: a tool for identification of mobility needs and evaluation of transport investments, Journal of Transport Geography 24, s. 142 154. DOI:10.1016/j.jtrangeo. 2011.12 .004 
[4] Van Wee, B. and Geurs, K., 2011. Discussing Equity and Social Exclusion in Accessibility Evaluations, EJTIR 11(4), s. 350367.

[5] Cascetta,E.,Carteni, A., Montanino, M., 2016. A behavioral model of accessibility based on the number of available opportunities, Journal of Transport Geography 51, s. 4558.DOI: 10.1016/j.jtrangeo.2015.11.002

[6] Ford, A. C., Barr, S. L., Dawson, R. J., James, P., 2015. Transport Accessibility Analysis Using GIS: Assessing Sustainable Transport in London, Isprs International Journal of Geo-Information 4(1), s. 124-149.

DOI: $10.3390 /$ ijgi4010124

[7] Gulhan, G., Ceylan, H., Ozuysal, M., Ceylan, H., 2013. Impact of utilitybased accessibility measures on urban public transportation planning: A case study of Denizli, Turkey, Cities (32), s. 102-112. DOI: 0.1016/j.cities.2013.04.001

[8] Özuysal, M. 2010. Şehirsel Yerleşimlerde Erişilebilirlik Ölçütünün Modellenmesi ve Kullanımı: Ulaşım Türü Seçimi Üzerindeki Etkisinin İncelenmesi. Dokuz Eylül Üniversitesi, Fen Bilimleri Enstitüsü, Doktora Tezi, 168s, İzmir.

[9] Özuysal, M., Tanyel S., Oral, M.Y., 2012. Fayda Esaslı Erișilebilirliğin Ulaşım Türü Seçimi Üzerindeki Etkisi, İMO Teknik Dergi, 23 (3), s. 59876016.

[10] Gülhan, G., Ceylan, H., Oral,Y., 2013. Ulaşım Talebinin Belirlenmesinde Erişebilirlik ve Arazi Kullanım Modellerinden Yararlanılması. 10. Ulaştırma Kongresi, İzmir, s. 47-55.

[11] Gülhan, G., 2014. Toplu Tașıma Planlaması ve A $\breve{g}$ Tasarımında
Erişilebilirlik Ölçütlerinin Kullanılabilirliğinin Araştırılması. Pamukkale Üniversitesi, Fen Bilimleri Enstitüsü, Doktora Tezi, 157s, Denizli.

[12] Istanbul Metropolitan Municipality, 2008. Management of Transportation Planning. Istanbul Transportation Master Plan Household Study, Istanbul.

[13] Litman, T., 2004. Transportation Affordability Evaluation and Improvement Strategies, http://www.vtpi.org/affordabilit y.pdf, (Erişim tarihi: 01.05.2016).

[14] Lau, J. C. Y., Chiu, C. C. H., 2006. Accessibility of low-income workers in Hong Kong, Cities 20 (3), s. 197-204. DOI: 10.1016 /S0264-2751(03)00013-1

[15] Preston, J., Raje, F., 2007. Accessibility, mobility and transport-related social exclusion, Journal of Transport Geography 15 (3), s. 151-160. DOI:

10.1016/j.jtrangeo.2006.05.002

[16] Grengs, J., 2012. Equity and the social distribution of job accessibility in Detroit, Environment and Planning BPlanning \& Design, 39 (5), s. 785800. DOI: $10.1068 / \mathrm{b} 36097$

[17] Ureta, S., 2008. To Move or Not to Move? Social Exclusion, Accessibility and Daily Mobility among the Low-income Population in Santiago, Chile, Mobilities 3 (2), s. 269-289. DOI: 10.1080/17450100802095338

[18] Lucas, K., 2012. Transport and social exclusion: Where are we now?, Transport Policy, 20, s. 107-115.DOI: 10.1016/j.tranpol.2012.01.013

[19] Hansen, W. G., 1959. How accessibility shapes land use, Journal of the American Planning Institute, 25, s. 73-76. DOI: 10.1080/01944365908978307 
[20] Ben-Akiva, M., Lerman, S., 1979. Disaggregate travel and mobility choice models and measures of accessibility. In: Hensher, D.A., Sopher, P.R. (Eds.), Behavioural Travel Modelling. Croom Helm, Andover, Hants, pp. 654-679.

[21] DfT, 2010. Transport Analysis Guidance, Personal Affordability Sub-Objective, http://www.dft.gov.uk/webtag, (Erişim tarihi: 01.05.2016)

[22] Handy, S.L., Niemeier, D.A., 1997. Measuring accessibility: an exploration of issues and alternatives. Environment and Planning A 29, s. 1175-1194. DOI: $10.1068 / \mathrm{a} 291175$

[23] Páez, A., Scott, D.M., Morency, C., 2012. Measuring accessibility: positive and normative implementations of various accessibility indicators. Journal of Transport Geography 25, 141153. DOI: $10.1016 / j . j t r a n g e o$. 2012.03.016

[24] Geurs, K. T., \& van Wee, B., 2004. Accessibility evaluation of landuse and transport strategies: Review and research directions, Journal of Transport Geography, 12 , s. $127-140$. DOI: $10.1016 /$ j.jtrangeo.2003.10.005

[25] van Wee, B., 2016. Accessible accessibility research challenges, Journal of Transport Geography 51 (2016), s. 9-16. DOI: 10.1016/j.jtrangeo.2015.10.018

[26] de Jong, G., Daly, A., Pieters, M., van der Hoorn, T., 2005. The logsum as an evaluation measure: Review of the literature and new results Transportation Research Part A-Policy and Practice 41(9), s. 874-889. DOI: 10.1016/ j.tra.2006.10.002

[27] Anas, A., 1981. The Estimation of Multinomial Logit Models of Joint Location and Travel Mode Choice from Aggregated Data, Journal of Regional Science 21(2), s. 223242. DOI: $10.1111 /$ j.14679787.1981.tb00696.x

[28] Niemeier, $\quad$ D.A., 1997. Accessibility: an evaluation using consumer welfare, Transportation 24(4), 1997, s. 377-396. DOI: 10.1023/A:1004914803019

[29] Limanond, T. and Niemeier D. A, 2003. Accessibility and modedestination choice decisions: exploring travel in three neighborhoods in Puget Sound, WA., Environment and Planning B-Planning \& Design 30(2), s.219238. DOI: $10.1068 / \mathrm{b} 12846$

[30] Daly, A., 1987. Estimating Tree Logit-Models, Transportation Research Part B-Methodological 21(4), s. 251-267. DOI: 10.1016/0191-2615(87)90026-9.

[31] Ben-Akiva, M., Lerman, S., 1985. Discrete Choice Analysis, The MIT Press, Cambridge, MA. 